\title{
The Character Cracked: The Waves and Woolf's New Way of Characterization
}

\author{
Yuan Yuan \\ School of Foreign Languages, Chongqing Normal University, Chongqing, China \\ Email: chuanwaiyuan@126.com
}

\begin{abstract}
The publishing of The Waves can be viewed as the climax Woolf's writing career, for this work could best represent her rebellion against conventional novel's poetics. Its unique form, of which the unique way of characterization is a crucial element, has almost completely overturned that of traditional novel thus aroused considerable debate. Combining close textural study with in-depth research into its relation with English literary tradition and its modern background, this thesis will try to present a full view of Woolf's brand new way of characterization demonstrated in this work yet already implied in her previous books.
\end{abstract}

Index Terms-Virginia Woolf, The Waves, characterization, motif-character

\section{INTRODUCTION}

Being one of the most innovative and influential novelist of last century, Virginia Woolf's entire publishing career can be described as an ever-regenerating creative process. By resetting the subject matter of the novel and constantly experimenting with its form, she finally ascends to that conspicuous height from which she can penetrate into life's flesh and fabric. Having long been viewed as a paradigm piece of modern literature, The Waves, her latest complete work, can best demonstrate this innovative spirit of Woolf's. It literally possesses no plot; therefore it almost seems an impossible task to provide an outline of its content. There are six main characters in this book, but they feel no warmth of real human beings. Actually each of these characters represents one unique perspective of life, and the all six of them point up the main body of this work, which mainly consists of their observations or meditations on the meaning of human existence, self-identity, the truths of personal as well as collective human life, etc.. It meets all requirements of Roland Bartes' le texte de jouissance, not all because of its notorious difficulty, but also because it challenges our various cherished conventions and so compels us to reexamine them.

But not everyone can appreciate this kind of jouissance, as many people failed to taste the intended sweetness after the bitterness accompanying their first bite. From its first publishing, its unique form, especially its brand new way of characterization, its absence of plot, and its poetic style, has aroused much confusion or even contempt among some of its readers. Such confusion not only came from amateur readers, whose reaction was natural enough; but it was also uttered by a few prominent writers or critics such as Arnold Bennett and E. M. Forster. The main concern of this thesis is to dispel such confusion or puzzle resulted from the unique quality of this work's artistic features. Because of the limited space, it will focus on only one aspect of them, namely, its distinctive way of characterization. By comparing Woolf way of characterization demonstrated in this work yet evolving from the start of her career with that of conventional novel, we can get an all-dimensional view of its strangeness. By revealing its functioning mechanism from the inside and placing it into the developing process of English novel, it can be expected that its exquisite inner glamour and significance for the literary tradition could get fully recognized.

\section{The Dissolution of CONVENTIONAL Character}

In Le Plaisir du Texte, Roland Barthes distinguishes two kinds of literary text: le texte de plaisir and le texte de jouissance. By confirming readers' notions of literary coherence and significance, the texte de plaisir brings them seeming pleasure. In contrast, by disrupting literary conventions, the texte de jouissance will cause shock or misery on the readers' side. But right because of such shock or misery, the latter kind of text should be cherished. Through such shock or misery, it compels readers to reconsider or question the various literary conventions that are hitherto invisible. As it is mentioned above, The Waves certainly belongs to this kind of text. With its disruption of those cherished conventions of novel, it has brought considerable jouissance to many readers. Among such disrupted conventions of novel, characterization is certainly one of the most foundational, thus resulting in considerable dissatisfaction. Once commenting on Woolf's characterization, Bennet (1975) says:

The foundation of good fiction is character creating, and nothing else. The characters must be so fully true that they possess even their creator. [...] I think that we have today a number of young novelists who display all manner of good qualities-originality of view, ingenuity of presentation, sound common sense, and even style. But they appear to me to be more interested in details than in the full creation of their characters. [...] they attach too much weight to cleverness, which is perhaps the lowest of all artistic qualities. 
E. M. Forster (1974) displays a similar view on this subject:

She could seldom so portray a character that is was remembered afterwards on its own account, as Emma is remembered, for instance, or Dorothea Casaubon, or Sophia and Constance in The Old Wives'Tale.

Because Woolf's characters are often lifted out of their social-economical conditions, Forster (1974) thinks that they lack life eternal. "The problem's center for Woolf," Forster comments, "is can he create character?" From these words, we can see both Bennett and Forster don't rank Woolf' characterization high and think it fails to meet conventional standards of successful characterization.

Here some words must be said on conventional characterization. Approximately, there are two means through which conventional characterization is accomplished. The characters either emerge from a chronological account of events, or from a static description of their personal features and their situation. Sometimes a character first appears as mystic, indeterminate figure, but after experiencing with him a series of events, we can finally deduce his personality. In other cases an initial static portrait of a character is produced while certain expectations of him are set. Then based on his violation or confirmation in time of such expectations, readers can get a complete idea of his personality. Some writers may prefer one of the two ways to another, but in most cases they are employed in combination. Jane Austin's characterization of Emma, the character successfully rendered in Bennett and Forster's opinion, can be approached in these two directions. Right at the beginning of the first chapter of Emma, we can see a static description of Emma's disposition, social-economical situation, family relationships, etc. is given. Yet it is only an initial portrait and Emma at this point is not yet "fully true", to use Bennett's words. More colors are waiting to be added to this initial portrait when Emma is put in relations with Harriet Smith, Jane Fairfax, Mr. Elton, Mr. Knightly and others.

So much has been said about conventional characterization, now if we turn to that of The Waves, the contrast can't be sharper. This work consists of nine chapters, every one of which is preceded by a short prelude in italics. These preludes are completely devoted to a description of the sun, the sea, and the garden, which bears no direct significance on the characters' experience. Apart from these preludes, the nine chapters are uniformly composed of direct interior monologues of the six main characters. Therefore there is no space left for an omniscient narrator's direct, static description of the initial conditions of the characters. Information about the colors of their eyes, their dispositions, and their class can be obtained in nowhere. So at least we can see the first way of conventional characterization has been abolished. As the preludes are all about the indifferent natural world, events and actions can't be detected there; as for the interior monologues, the very name by which we address them implies that they are more concerned with elements of the characters' inner life than the actual actions or events of the outside world. It is an undeniable fact that in Woolf's previous works, such as Mrs. Dalloway and To the Lighthouse, readers could salvage some broken pieces of the characters' living experience here and there from their consciousness. But in this work, such expectation on the readers' side is doomed from the start, for all the direct inner monologues making up the main body of this work refer rarely to the material world. Therefore the other way of conventional characterization also has no space to breathe in this work. When characters are robbed of their appearance and experience, what will become of them?! Having completely abandoned conventional means of characterization, how can Woolf breathe life into her characters?

\section{FROM CHARACTER TO MOTIF-CHARACTER}

"Motif" is a term usually employed in analysis of poetry or music. A motif can be approached as one of the sub-themes of a poem, through the interplay of which the overall theme of the poem is constructed. Borrowing it to our discussion of character, we mean by motif-character a new kind of character which equals a single quality or an element of conventional 'round' characters. In context of our analysis of The Waves, we designate this name to its characters because all the six main characters are rendered in such a way that each of them represents one angle of human perception, as Leonard Woolf (1957) reveals:

[Virginia Woolf] wanted to take six persons, intimate friends, all different, and show their relations to the fundamental things in human existence: friendship, love, life, and death. At the same time [...] she wanted to show that these six persons were several facets of a single complete person.

So the six characters represent six perspectives through which life is grasped. One must notice that not all Woolf's characters can be addressed as motif-character. Though almost all her characters in her mature works have attained a sense of abstractness as a result of Woolf's reluctance to reproduce actualities of life, only in The Waves her characters achieve that kind of purity so that they can be designated this name. Characters such as Mrs. Dalloway in Mrs. Dalloway and Mrs. Ramsay in To the Lighthouse are also revealed through their consciousness, but what concerns their mind is varied and rich, and their perception is multi-directed. In contrast, in The Waves, the singleness, or purity of its characters' perception is maintained from the beginning to the end.

However, a further question is raised right by such singleness or purity of the motif-characters: how should we approach them? Addressing character, Henry James (2003, P. 501) uttered his famous comment: "what is character but the determination of incident? What is incident but the illustration of character?" Conventionally, one major way to approach character is through actions. But this approach will certainly not do with our motif-characters, for, as it has made clear previously, they are not represented through their actions. Yet a useful analogy can be drawn from Henry James's comment: what is motif-character but the determination of perception; what is perception but the illustration of motif-character? So the motif-characters can be approached through their respective quality of perception, through the 
unique texture of their mind. Critics have noticed that there are three fundamental questions constantly engaging Woolf's characters' mind. The first one is an ontological question about self-identity, as it has been put forward by Bernard in The Waves: Who am I? The second question is about human cognition, about the possibility to lay hands on ultimate truths of life, just as Bernard wants to get the "true story" of life in The Waves, or Mr. Ramsay tries to reach "R" of the alphabet in To the Lighthouse. The third question concerns ethical values, or the fundamental meaning of life, as Lily Briscoe in To the Lighthouse asks: what is the meaning of life? This summary is concise enough, but it can be further refined. In fact, question one and three are already contained in question two. One's self, that wedged-shaped core of darkness, can be defined by the way he approaches life; also the meaning of existence should be found in human endeavors to resolve the irresolvable, to grasp the ungraspable. A tinge of Hegel's Master-slave dialectics can be detected here: just as the slave, by reforming nature, finally manages to assert his identity as master and attain the meaning of his existence, the motif-characters, through their respective endeavors to define life, defines their own self-identity and attain their own meaning of life.

From what has been said above, an effective way to define the motif-characters is to see how they define life. In The Waves, life's indifferent presence can be felt all throughout, of which the universe presented in the nine preludes, is the perfect embodiment. The nine preludes preceding each chapter have long caught critics' attention. As they uniformly concern themselves with the sun, the sea and the garden, and bear no immediate significance to the characters experience, many efforts have been devoted to explore the relation between the two. Numerous essays are trying to testify an analogous correspondence between the universe in these preludes and the characters' experience. Such correspondence sounds reasonable enough, but indulging themselves in their ecstasy about this finding, critics often neglect another important function of these preludes: with the indifferent universe presented in these preludes looming eternally in the background of the characters' endeavors, a tension bearing profound formal and thematic significance is created. One familiar with Woolf's works should not feel strange about this arrangement. It reminds one of the strikes of Big Ben in Mrs. Dalloway and the Time Passage part in To the Lighthouse; only here it appears much more compelling. As the threatening, indifferent figure of nature has been set up, the characters all set out to penetrate it from their own individual perspective. The unique quality of each character's perspective is his/her motif. The motif of Bernard is language; Neville intellect; Louis commerce; Rhoda fantasy; Susan maternity; and Jinny sensuality.

Bernard believes in the power of words, phrases and stories, and accordingly he approaches life by forging words, making up phrases, and telling stories. Even as a child, Bernard begins to feel the pressure of life's indifference, as he recalls: "[...] when I was a child, the pressure of an enemy had asserted itself; the need for opposition had stung me (The Waves, P. 152)." From then on, he keeps felling this pressure, feeling that "disorder, solidity and corruption surround us" (P. 165). The weapon he takes up to fight against that enemy is words, phrases and stories. On every crucial point of his life whenever he needs help, he relies on the power of them. In the mystic garden of his early childhood, story-telling is the means by which he consoles Susan, as he believes that "[...] words, moving darkly in the depth of your mind, will break up this knot of hardness in your (Susan's) hanker-chief (P. 7)." Later, when he and the other five children are leaving home for school in London, words, phrases and stories are the means by which he can restrain himself from crying, as he thinks that he "must make phrases and phrase and so interpose something hard myself and the housemaids, the stare of clocks, staring faces, indifferent faces, or I shall cry (P. 16)." At school, Bernard becomes more and more aware of his talent in handing words or making stories, and he begins to record his observation of life in his mind's notebook:

"I note the fact for future reference with many others in my notebook. When I am grown up I shall carry a notebook-a fat book with many pages, methodically lettered. I shall enter my phrases. Under B shall come 'butterfly powder' (P. 19)."

When he is telling stories, he is mostly at ease:

"Let me talk. The bubbles are rising like the silver bubbles from the floor of a saucepan; image on top of image. [...] I must open the little trap door and let out these linked phrases in which I run together whatever happens, so that instead of incoherence there is perceived a wandering thread, lightly joining one thing to another (P. 26)"

Numerous more examples can be drawn to testify words, phrases, and stories as Bernard means to grasp life, but there is no need to add more. In sum, they serve three basic functions for Bernard: as the means of cognition, as the source of life's meaning, and as the vital element of his self-identity. He once explicitly declares: "I am a natural coiner of words, a blower of bubbles through one thing and another (P. 35)." Therefore, we say the motif of Bernard is language.

\section{Motif-CHARACTER AND WOOLF's NeW ARTISTIC Vision}

Literary masterpieces are not isolated islands; rather they are always integral parts of the whole literary tradition. If a single literary piece is only a single utterance among many others making up the literary tradition, then it is not enough to only focus on its constative significance, to use a linguistic term, its performative significance must be taken into account, too. By constative significance we mean the significance of a literary work observed in isolation, while by performative significance we mean significance of this work understood in relation to other works inside the literary tradition. In our present attempts to fully appreciate the splendors of this work's characterization, it is inadequate to only concentrate our discussion on its internal qualities; instead, to make our study complete, it is more than necessary 
to examine how it is related to conventional English novel's characterization. Generally, the relation of this work's characterization to that of conventional novel can be described more as rebelling than as inheriting. This rebelliousness is mainly manifested in two levels, namely the level of artistic vision and the level of artistic expression. The former is rebellion on mind, while the latter is rebellion on paper.

One of the main functions of art is to provide people new perspectives of life. Absorbed in their daily concerns, people's perception becomes to a great extent automatized or habitualized, so they fail to grasp life's freshness. Art, by providing new angles and adjusting the viewing distance, can regenerate our mode of perception from the automatic or habitual to the innovative or the artistic. Shklovsky (1986) makes this quite clear in his influential article Art as Technique:

The technique of art is to make objects 'unfamiliar', to make forms different to increase the difficulty and length of perception, because the process of perception is an aesthetic end in itself and must be prolonged. Art is a way of experiencing the artfulness of an object [...].

For Virginia Woolf, the main reason why she chooses to rebel against conventional novel is right because she feels conventional novel has lost this power to refine perception.

The conventional novel Woolf set out to write against is the $19^{\text {th }}$ century realistic and naturalistic novel. Her most explicit attack on these two schools comes in her essay Modern Fiction. In this essay she calls the three representative figures of contemporary realistic and naturalistic schools, namely Wells, Bennet, and Galsworthy, 'materialists'. She (Woolf, 1984) means by this term that works of these three, with their main body devoted to represent the superficial details of life, fail to grasp its essentials:

So much of the enormous labor of proving the solidity, the likeness to life, of the story is not merely labor thrown away but labor misplaced to the extent of obscuring and blotting out the light of the conception. The writer seems constrained, not by his own free will but by some powerful and unscrupulous tyrant who has him in thrall, to provide a plot, to provide comedy, tragedy, love interest, and an air of probability embalming the whole so impeccable that if all his figures were to come to life they would find themselves dressed down to the last button of their coats in the fashion of the hour. The tyrant is obeyed; the novel is done to a turn. But sometimes, more and more often as time goes by, we suspect a momentary doubt, a spasm of rebellion, as the pages fill themselves in the customary way. Is life like this? Must novels be like this?

Here Woolf is criticizing the representational quality of her contemporaries' novel. The text of such novel is amassed with numerous trivial details of characters and their material surroundings, to ensure the resemblance of the fictional world to the real world; and its characters are always busily engaged in their comic or tragic worldly pursuits to carry out the novel's didactic function. Novel as such focuses only on the surface of life, seldom looking within to grasp its meaning in depth. Woolf's criticism of conventional novel here reminds one of Plato's criticisms of imitative poetry in Republic. In the example provided by Plato (2003), a carpenter makes a bed in imitation of its ideal; a poet portray a bed in imitation of the bed made by the carpenter; so the poet's bed is an imitation of imitation, therefore "thrice from truth". Applying this criticism of Plato's on imitative poetry to novel of the realistic or naturalistic school, we can find it is rather fitting. The realists or the naturalists lay enormous efforts to make the world portrayed in their works seem real or natural, to ensure their verisimilitude, but as such efforts are only concentrated on the material surface, their works are also far from truth. For Woolf, such old conventions of novel are like a tyrant, in obeisance to which novel loses its capacity to grasp life. Nietzsche, in his Birth of Tragedy, attributes the downfall of Greek tragedy to its abandonment of the Dionysian impulses in submission to the restrictive Apollonian conventions. Woolf, in this essay of hers, has sensed a similar risk faced by English novel, as its body is burdened with rotten conventions while its grasp on life is loosening. Now the need for change and revolution is more than urgent.

As conventional novel's mode of perception has become stale, a new mode must be introduced. In the same essay, Woolf (1984, P. 149) proposed her new mode of perception:

Look within and life, it seems, is very far from being "like this". Examine for a moment an ordinary mind on an ordinary day. The mind receives myriad impressions-trivial, fantastic, evanescent, or engraved with the sharpness of steel. From all sides they come, an incessant shower of innumerable atoms; and as they fall, as they shape themselves into the life of Monday or Tuesday, the accent falls differently from of old; the moment of importance came not here but there; so that, if a writer were a free man and not a slave, if he could write what he chose, not what he must, if he could base his work upon his own feeling and not upon convention, there would be no plot, no comedy, no tragedy, no love interest or catastrophe in the accepted style, and perhaps not a single button sewn on as the Bond Street tailors would have it. Life is not a series of gig lamps symmetrically arranged; life is a luminous halo, a semi-transparent envelope surrounding us from the beginning of consciousness to the end. Is it not the task of the novelist to convey this varying, this unknown and uncircumcised spirit, whatever aberration or complexity it may display, with as little mixture of the alien and external as possible?

From this short passage above, we can see the new mode of perception proposed by Woolf is sharply different from the old one on its object, its means, and its aims. Speaking of its object, this new mode of perception has shifted its focus from the outside to the inside, from the material world to human consciousness. Later in this essay, Woolf explicitly points out that the point of interest for the moderns now lies very likely in the dark place of human psychology. If a realist or a naturalist usually focuses on a character's appearance and experience, the modern novelist 
would directly examine the texture of his mind, exploring the myriad impressions she has received on an ordinary day. Then, about the means of this new artistic vision, one can see it relies on the combination of sense and sensibility. On one hand it relies on human sensibility to receive the colors, scents, sounds, etc. of the outside world, to form various impressions of existence. Such impressions are various, private, and highly individual, a perfect example of which is the rich sensations triggered by a piece of sugar or music in the protagonist mind in Proust's Remembrance of the Things Past. But only this receptive sensibility is not enough. If so, the new novel would be only a passive accumulation of various impressions, reducing itself down to a kind of psychological naturalism. Therefore the new mode of perception must rely also on rational power to grant those impressions an aesthetic form, to grasp their significance. Finally, speaking of this its aim, this new mode of perception always involves itself in addressing fundamental questions of life. If conventional novel's characters' mind is engaged with questions about love, fortune, or honor, mind of Woolf's characters would be engaged with questions about life's essentials, such as "what's the meaning of life?", "Who am I?", "What is reality?"... For Woolf, modern novel should not concern itself only with the articles on life's surface, rather it should devote itself to rendering life the "luminous halo", the "semi-transparent envelope" clear, to providing justification for existence, and to grasping its fundamental truths.

This new mode of perception best manifests itself in The Waves, the work we are addressing. Except for the nine short preludes, the whole body of this work is devoted to explore the six main characters' consciousness, with the importance of the material world deduced to a minimum. The six characters represent six different perspectives of life. Through the characters' sensations, impressions, reveries, and their efforts to reach a synthesis of them, life is grasped. What concerns the characters as well as the whole work is the quest for the essential things, such as self-identity, human cognition, and meaning of life. The Waves can be understood as a paradigm of the mode of perception advocated by Woolf.

\section{Motif Character as New Mode of Artistic ExPression}

New mode of perception naturally results in new mode of artistic expression. On the surface, the change taking place on artistic vision seem parallel with the change taking place on artistic expression; the former is a change on mind, while the latter on paper, as we have mentioned previously. In depth, the two are actually one, for the latter change is nothing but the further development or manifestation of the former. Pondering over this relation between artistic vision and its representation draws us back to the old argument about the relation between "content" and "form". Modern literary criticism has long discarded the notorious idea of 'form' being only the tubes through which content flows through, or content being the substance hiding in the sugar-clothes of form. The origin of such idea can be traced back at least to Horace's (2003) Art of Poetry, in which he identifies the main advantage of poetry as to teach and delight. In his notion, the delighting elements or the formal features of poetry are in service to its teaching elements or its content. Nowadays, however, the unity of the two is widely acknowledged in literary criticism. Commenting on this subject, in The Art of Fiction Henry James (2003, P. 506) compares the relation between content and form to that between needle and thread, either of which cannot be separated from the other. He (Ibid., P. 509) adds latter: "the deepest quality of a work of art will always be the quality of the mind of the producer [...]. His remark is explicitly relevant to our present discussion: the artistic quality of a modern novel will always be the quality of the modern novelist' mind, and the change of a modern novelist's mode of perception will always bring in new poetics of novel. In the case of Virginia Woolf, her new mode of perception first results in a new way of characterization.

In accordance with the new mode of perception she has proposed, Woolf's new way of characterization consists of three aspects. Firstly, characters in her works are purged of irrelevant details of their states in the material world, with the weight now put on their inner world. Woolf wants her novel to tell its readers little about the houses, incomes, occupations of its characters, and it will have little kinship with the sociological novel or the novel of environment. Its characterization will focus on the feelings, impressions, and reveries on its characters' mind, exploring "that large and important part of life consists in our emotions towards such things as roses and nightingales, the dawn, the sunset, life, death, and fate [...] (Woolf, 1966).”

But only this shift from the outside to the inside is far less than enough, for the inside has to be managed and its elements have to be selected. A novelist must select from the multitude of his impressions and experiences those that bear most profound significance to his theme or his value of life, as Woolf (1966, P. 228) put it: "he will have extended the scope of his interest so as to dramatize some of those influences which play so large a part in life[...]" This aspect of selection in Woolf's characterization is extremely important, because it prevents her characterization from falling down into merely passive imitation of the mind, and distinguishes her from many other novelists whose interest lies also in human consciousness. It reminds one of the principles of selection in post-impressionism painting, whose relation to Woolf's poetics of novel is widely acknowledged. Of all Woolf's works, this second aspect of characterization manifests itself most explicitly in The Waves, as the six main characters are purified into six perspectives of life. They possess little "roundness" of conventional characters, and can even be described as rather "flat". But "roundness" or "likeness" should not be the sole standard to judge good characterization; instead, it should be judged in consideration of its efficiency to serve the overall concern of a work. For Woolf, the first and foremost concern of a work is to grasp essential meanings of life. Speaking of its service to the accomplishment of this aim, Woolf's characterization in The Waves is undoubtedly successful, as the characters" "flatness" enables their "sharpness", which cut deep into life like a 
blade.

Thirdly, there is a formal contrast built among the characters, which enriches the variety of distance and angle of characterization. One of the finest examples of the formal contrast in question comes in the last chapter when Bernard is examining a willow tree in his mind. Focusing his mind's eye on this willow tree, he swiftly switches from one's perspective to another's to get his observation. By contrasting his perspective with that of other motif-characters, Bernard gets a more distinct picture of himself. On the readers' side, too, an additional picture of Bernard can be obtained by contrasting him to the others. This formal contrast built among the motif-characters is another way of characterization, in addition to the first way of characterization analyzed in the previous part. If in the first way the motif-characters are defined through their relation to life, in the present way they are defined through their relation to each other. By constantly contrasting their own perception of life with that of the others, they obtain a more accurate picture of themselves. But this formal contrast's bearing on characterization doesn't end here. From our analysis above, we can see in Bernard's mind portraits of the others are formed. In the same way, in every other motif-character's mind, such portraits of the others can also be obtained. So every motif-character's mind can be seen as a reservoir where information of the others is stored. If readers collect such fragmentary pieces of information of one motif-character from the others' minds and assemble them together, another picture of him can be obtained. Therefore it is reasonable to say a third way of characterization is implicit in the formal contrast in question. If "the foundation of good fiction is character creating", according to Arnold Bennet, now it is beyond any doubt that Woolf done a superb job to lay a sound foundation for this work of hers. In quite a different way, she enables her characters achieve a kind of "roundness" that can compete with any roundness achieved through conventional characterization. Each motif-character in The Waves is portrayed from three different angles, namely, from their relation to life, from their relation to each other, and indirectly from other one's minds. This multi-angle characterization grants Woolf's motif-characters a new "roundness" that enables them to appear no less vivid or lively than Austin's Emma or Dickens's David Copperfield.

\section{AN APOLOGY FOR MOTIF-CHARACTER}

In the beginning part of this thesis, we have mentioned that Woolf's new way of characterization has aroused considerable confusion either in common readers or professionals' part. Now towards the end, after much IN and OUT of the text, it's the most suitable time to finally dispel it.

The first question need to be answered in order to dispel charges against Woolf's characterization is: What is the standard against which the quality of an artifice is judged? Is it the "likeness" to life, the accumulation of details about people's appearance, marriage, family, occupation, class, fortune, love, etc.? Certainly not so. Reference to the real world should not be the sole criteria of good art; it exists somewhere else.

"Questions of art are questions of execution," as Henry James (2003, p. 503) puts it: "we must grant the artist his subject, his idea, his donneé; our criticism is applied only to what he makes it." "If we pretend to respect the artist at all," he adds: "we must allow him his freedom of choice, in the face, in particular cases, of innumerable presumptions that the choice will not fructify (ibid)." Applying this principle to the art of fiction, we should acknowledge that "the advantage, the luxury, as well as the torment and responsibility of the novelist, is that there is no limit to what he may attempt as an executants - no limit to his possible experiments, efforts, discoveries, successes"(Ibid). So technically, to achieve a certain aim, a novelist may have many choices at hand. A certain artistic effect can be created through different means, and a certain subject matter can be rendered in various ways. The means or the way chosen by a novelist should not be judged for their own sake, but by their "efficiency" or "usefulness" displayed in aiding the novelist to achieve his end.

It is absurd to range Woolf low, just because she doesn't favor the representational aspect of conventional novel, nor is it just to consider her characterization as a failure only because her characters possess little conventional "roundness". Successful characterization may be accomplished from the outside, by focusing on appearance and experience; or from the inside, by exploring the realm of impressions and reveries. Each way is lawful; neither is illegal. No one is privileged by birth. To see which is better, they have to be judged in reference to their contribution to the overall end of a work. In accomplishment of this overall end of a work, characters must work hand in hand with its other elements. E. M. Forster (1955) himself acknowledges this in Aspects of the Novel: "we are concerned with the characters in their relation $[\ldots]$ to a plot, a moral, their fellow characters, atmosphere, etc. They will have to adapt themselves to other requirements of their creator."

So characterization itself is not the end, but one of the many means through which a novel accomplish its certain goal in general. Good characterization possesses no essential quality such as vividness or "roundness". It distinguishes itself by its "performance", its efficiency in helping the novelist accomplish his goal. This reminds us of the character of Percival in The Waves, whose value lies in his "supportiveness", his contribution to the interior structure of the whole work. Similarly, the virtue of the six main characters in this work lies not in their "likeness" to some real person on earth, but in their service to the overall goal of this work: to grasp the truth of being. Viewed from this perspective, their "flatness" is their bliss; it's the source of their perception" "sharpness". Judging from their resemblance to real human beings, they are indeed poorly rendered. But judging from their performance, their functioning, they are most artfully created. As Forster himself has identified this standard of judgment in his own study of novel, it is quite puzzling why he can't detect its perfect execution by Woolf in her works. Maybe it's just easier said than done, as the old saying goes. 
New manner of artistic expression is always related to new form of artistic vision. As the charges against Woof's artistic expression have been answered, it's time to turn to those against her artistic vision. Here again a question has to be answered: are there some essential qualities by which the superiority of one artistic vision over that of another is judged? What is truth? What is reality? Is stirring a cradle reality, while meditating under the beams of the lighthouse not? Is one's vision, composed of impressions, moments, and patterns, necessarily inferior to that of another's, which consists of scenes and plots? Are one's concern over the War, the kings, and the living conditions of the working-class human, while another's concern, over self-identity, meaning of life, and the possibility of knowledge, naturally inhuman? Definitely not so. "Humanity is immense, and reality has a myriad of forms (James, 2003, P.499)." The War, the kings, and the living conditions of the working class, or the impressions, moments, and patterns, to quote Henry James (Ibid., 507) again, "they are all particles of the multitude life with which the novel deals", and "surely no dogma which pretends to make it lawful to touch the one and unlawful to touch the other will not stand for a moment on its feet". We agree with Woolf's (1984, P. 146) conviction that there is no "proper stuff" of fiction, and that "everything is the proper stuff of fiction, every feeling, every thought; every quality of brain is drawn upon; no perception come amiss". The superiority or inferiority of an artistic vision should be judged, as that of characterization is, also by its efficiency, its "usefulness" in perceiving life, by its potential to open new vistas of life.

But Woolf deserves more than an equal treatment; she deserves an exceptional treatment. In context of modern time, her artistic vision, compared with that of the realists' or the naturalists', is more capable of grasping life's meaning. A brief survey of the research on modernization carried out by Max Weber and Frankfurt School can testify this. As modernization brings in unprecedented material prosperity, it also brings in unprecedented spiritual famine. People in modern time are losing the sense of "organic" existence possessed by people of pre-industrial societies, and the sense of alienation becomes more and more acute. Modern problems go hand in hand with modernization. Such problems can be attributed to two fundamental ones: "the loss of meaning" and "the loss of freedom". By loss of meaning, we mean that when traditional ethical values and religious faiths are replaced by instrumental knowledge, modern people have lost their life's guidance. By loss of freedom, we mean that as subdivision of labor goes further and as instrumental rationality begins to dominate people's judgment, modern people are losing their freedom to make choice over their lives; their moves are more and more prescribed by those mechanical laws of their society, of which they are only extremely tiny, insignificant parts. An explicit symptom of such modern problem is that people now don't work, talk, behave, smile, etc. as they WANT TO, but as they ARE SURPPOSED TO; their actions, words, and expressions fail to represent their true states of mind. Turning back to our context, now we can see way Woolf's artistic vision is superior than that of the realists' or the naturalists'. If dialogues, actions, and other outward details now fail to reflect true stated of one's mind, why enormous efforts are still laid out to represent them? Why not turn to one's mind itself? Why not turn from the phantoms on the wall of the cave, to look squarely at the fire itself? If the realists or naturalists are marked by their loyalty to appearance and experience, then under modern conditions, such loyalty, once being the source of their glory, now inevitably turns into their undoing. For in modern time, thanks to division of labor and explosion of instrumental knowledge, individuals are robbed of their faces and features to be submerged into some functioning "class" or "group"; and their experience, if they must have some experience after all, is more of an experience of fragmentation and nihilism than that of willful action. If now both action and appearance are almost impossible, doesn't the realism, being loyal to them, turn into a kind of idealism? In contrast, does the modern fiction advocated by Woolf, which accepts this impossibility but is often accused of aestheticism or idealism, turns out to be much more realistic? Therefore, the modern novelist, to quote Woolf (1984, p.146), "has to have the courage to say that what interests him is no longer 'this' but 'that'; out of 'that' along must he construct his work". For the moderns, "that", the point of interest, lies very likely in the dark place of psychology.

\section{CONCLUSION}

To sum up, in The Waves Woolf has granted a brand new form to her work, of which the characterization is certainly a major element. By transforming conventional character into motif-character, Woolf has done a profound contribution to the evolvement of English novel, making it a more suitable artistic form for the representation of modern life. Though unique and daring, the coming forth of such new means of artistic expression follows the natural logic of the novel's development. Even its relation to its previous conventions is more of rebelling than inheriting, they nevertheless serve as the base for such denial. More importantly, one should look into the in-depth motivation for such rebellion. After all, rebellion is not for its own sake. The change on artistic expression resulted from the change on a new generation's artistic vision, which in turn resulted from the change of man's living conditions under new circumstances. If art is the dazzling violet in May, one should not view it as a flouting blossom in the air; on the contrary, one must feel its roots deep in the rich, fertile earth that is everyday life and its age. The Waves and its unique artistic features represented by its innovative characterization is certainly such a sight-catching blossom, and the rich soil underneath is certainly the life in its author's era. No one here is insisting the old-fashioned parallel cause-effect relation of life and art; on the contrary, what we get from our research is the wholeness of man's living experience, of which art may be viewed as its expression, or just a part of it, though usually the most breathtaking, glamorous part. 
[1] Bennet, Arnold. (1975). Is the Novel Decaying?. In Robin Majumdar \& Allen Mclautin (Eds.), Virginia Woolf: The Critical Heritage. London: Routledge and Kegan Paul. 113-124.

[2] Forster. E. M. (1955). Aspects of the Novel. New York, Harcourt.

[3] Forster, E. M. (1974). Virginia Woolf. In Oliver Stallybrass (Ed.), Two Cheers for Democracy. E. M. Forster: Avinger Harvest Edition. Harmondsworth: Penguin Books 1974. 257-266.

[4] Horace. (2003). Art of Poetry. In Naiqiang Yao (Ed.), Western Classics in Literary Criticism: From Plato to Henry James. Shanghai: Foreign Language Education Press. 42-57.

[5] James, Henry. (2003). The Art of Fiction. In Naiqiang Yao (Ed.), Western Classics in Literary Criticism: From Plato to Henry James. Shanghai: Foreign Language Education Press. 496-509.

[6] Plato. (2003). In Naiqiang Yao (Ed.), Western Classics in Literary Criticism: From Plato to Henry James. Shanghai: Foreign Language Education Press. 8-11.

[7] Shklovsky. (1986). Art as Technique. In Robert Con Davis \& Ronald Schleifer (Eds.), Contemporary Literary Criticism. New York: Longman. 264-279.

[8] Woolf, Leonard. (1957). Virginia Woolf and The Waves. Listener, June 28, 1957, 1.

[9] Woolf, Virginia. (2000). The Waves. Ware: Wordsworth Editions Limited.

[10] Woolf, Virginia. (1984). Modern Fiction. In Andrew McNeillie (Ed.), The Common Reader: First Series. New York: Harcourt. 146-154.

[11] Woolf, Virginia. (1966). In Leonard Woolf (Ed.), Collected Essays. London, The Hogarth Press. 224-231

Yuan Yuan was born in Sichuan, China in 1986. He received his M.A. degree in literature from Shanghai International Studies University, China in 2010.

$\mathrm{He}$ is currently a lecturer in the School of Foreign Languages, Chongqing Normal University, ChongQing, China. His research interests include modern English literature. 